\title{
神経移植を要した巨大耳下腺多形腺腫例
}

\author{
小坂 道也・堀泰高・萩池 洋子・赤木 博文*
}

\section{Giant Pleomorphic Adenoma of Parotid Gland ; A Case Report}

\author{
Michiya Kosaka, Yasutaka Hori and Yoko Hagiike \\ (Kagawa Rosai Hospital) \\ Hirofumi Akagi \\ (Okayama University)
}

\begin{abstract}
We report a case of giant pleomorphic adenoma of parotid gland. The patient was a 66-yearold female who first noticed the mass 30 years previously, although the mass had not been treated. The tumor gradually enlarged and on examination at our hospital on March the third 1999, the tumor was $13 \times 11 \times 9 \mathrm{~cm}$. The patient underwent total parotidectomy and since the tumor involved a facial nerve, the nerve was resected and we grafted the cervical sensory plexus. Midline mandibulotomy was performed because the tumor extended to the parapharyngeal space. Histopathologically, there was no evidence of malignancy. Facial palsy was gradually improved postoperatively and there has been no recurrence for two years.
\end{abstract}

Key words : pleomorphic adenoma, nerve graft, facial palsy

はじめに

耳下腺多形腺腫は耳下腺腫瘍のなかで最も頻度が高 く12), 日常診療で比較的多く遭遇する疾患であるが, 近年は腫瘍と診断されれば, 腫瘍の悪性化, 腫瘍の増大 による美容的な問題などから, 原則的に早期に手術が行 われる。

そのため巨大な耳下腺腫瘍に遭遇する機会はまれであ る3)が，今回，30年前に他院で腫瘍と診断されたが，手 術を拒否し，30年後に手術を行い，手術に際して顔面神 経の切除怙よび神経移植を要した巨大耳下腺多形腺腫を 経験したので文献的考察とともに報告する.

\section{症例}

患者: 66歳, 女性.

主訴：左耳下部腫瘤.

既往歷 : 交通事故による顔面外傷後の左前額部顔面神

\section{経麻痺 (20年前).}

現病歴 : 約 30 年前に左耳下部腫瘤に気付さ, 他院で耳 下腺腫瘍と診断され手術を勧められたが，手術を拒否し そのまま放置していた，その後腫瘤は徐々に増大し巨大 となってきたため，近医を受診し平成11年 3 月 3 日，当 科紹介となった。

局所所見：左耳下部から後頸部にかけて $11 \times 11 \mathrm{~cm}$ の八頭状の隆起性の弾性硬の腫瘤を認めた(図 1 )。可動 性は不良で，皮膚との癒着は認めなかった。腔所見で は左前口蓋弓から口蓋扁桃にかけて腫脹を認めた。腫瘤 部の疼痛, 圧痛は認めなかった。 20 年前の交通事故によ る顔面外傷後の左前額部顔面神経麻痺 (完全麻痺) 以外に 顔面神経麻痺は認めなかった．スコアは40点法4)で34点 であった、頸部にリンパ節の腫脹を認めなかった．開口 制限も認めなかった，その他, 耳, 鼻, 喉頭に異常を認 めなかった。 


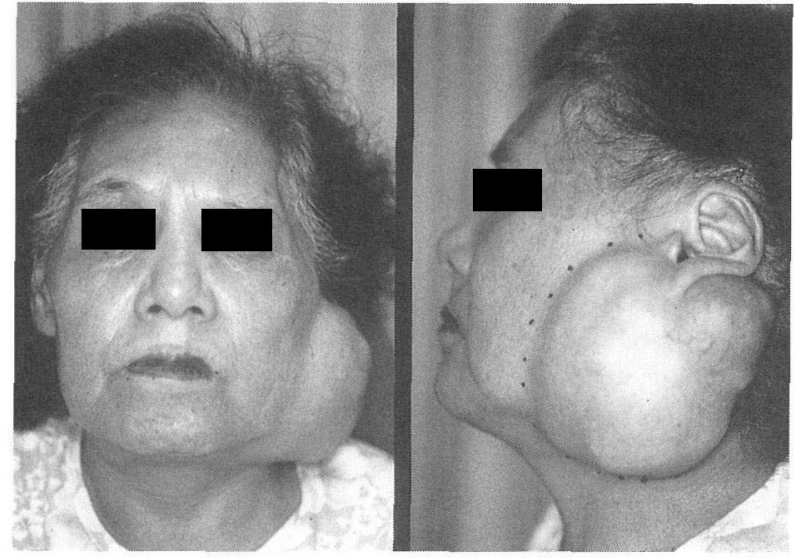

図 1 入院時所見

左耳下部に巨大腫瘤を認め左前額部顔面神経麻痺(交通 事故後)を認める.

検查所見：MRI 亿て左耳下部から左副咽頭間隙にか けて巨大な腫瘍性病変を認めた（図 2 )。T1 で低輝度, T2 で高輝度で，腫瘍は耳下腺深葉から副咽頭間隙にか けてダンベル型を呈していた。頸部に有意なりンパ節の 腫脹は認めなかった。穿刺吸引細胞診はクラス正bで 悪性像はなく, 多形腺腫が推定された。一般血液検查に 異常を認めなかった。

腫瘍の悪性化, 術中顔面神経の切断, 下顎離断などの 可能性を説明し患者の同意が得られたため，平成11年 3
月23日手術を行った。

手術所見: 手術は全身麻酔下に経鼻挿管にて行った. 耳前部から顎下部にかけてS 字状切開を加光た。後方か ら腫瘍を剥離していき, 顔面神経本幹を露出した。腫瘍 は娘結節を多数形成し増大して和り，そのなかを本幹が 貫く形になっていた，末梢で前額枝，䫅骨枝，頓枝，下 顎緑枝をすべて露出した。末梢に泾いても神経は完全に 多数の娘結節の間を貫く形になって括り(戝 3), 腫瘍摘 出のためには神経の保存は不可能々判断し本幹と末梢側 でそれぞれ神経を切断した，次に額二腹筋後腹，茎突舌 筋, 茎突下顎勒帯を切断乙茎状突起を外側に骨折させ, 用手的に副咽頭間隙の腫湟を剥離していったが最上方の 部分で外側の巨大腫瘍が操作の支障となり, 血管, 神経 を保存しての安全な剥離が困難と考光, 皮虚切開を延長 し下㴿正中離断を行い，明視下に腫瘍を全摘した。腫瘍 と周囲との癒着は認めなかった。術中病理所見は多形腺 腫で, 悪性像は認めなかった。切除後, 神経刺激装置を 用いて，切断した顔面神経の末梢の枝を旮れぞれ刺激し 眼瞼, 上口唇, 下口唇が最も大きく動く枝を 3 枝選び, 左大耳神経を中枢側に剥離していき採取した頸神経叢 を用いて本幹とそれぞれの枝の間に 8-0ナイロンで神 経移植を行った(図 4 )，神経吻合は神経上膜吻合で行っ た。余剩皮膚を切除し閉創した。

摘出標本 (図 5 ) : 腫瘍は $13 \times 11 \times 9 \mathrm{~cm}$ で, 八頭状で 割面は黄白色で充実性であった。
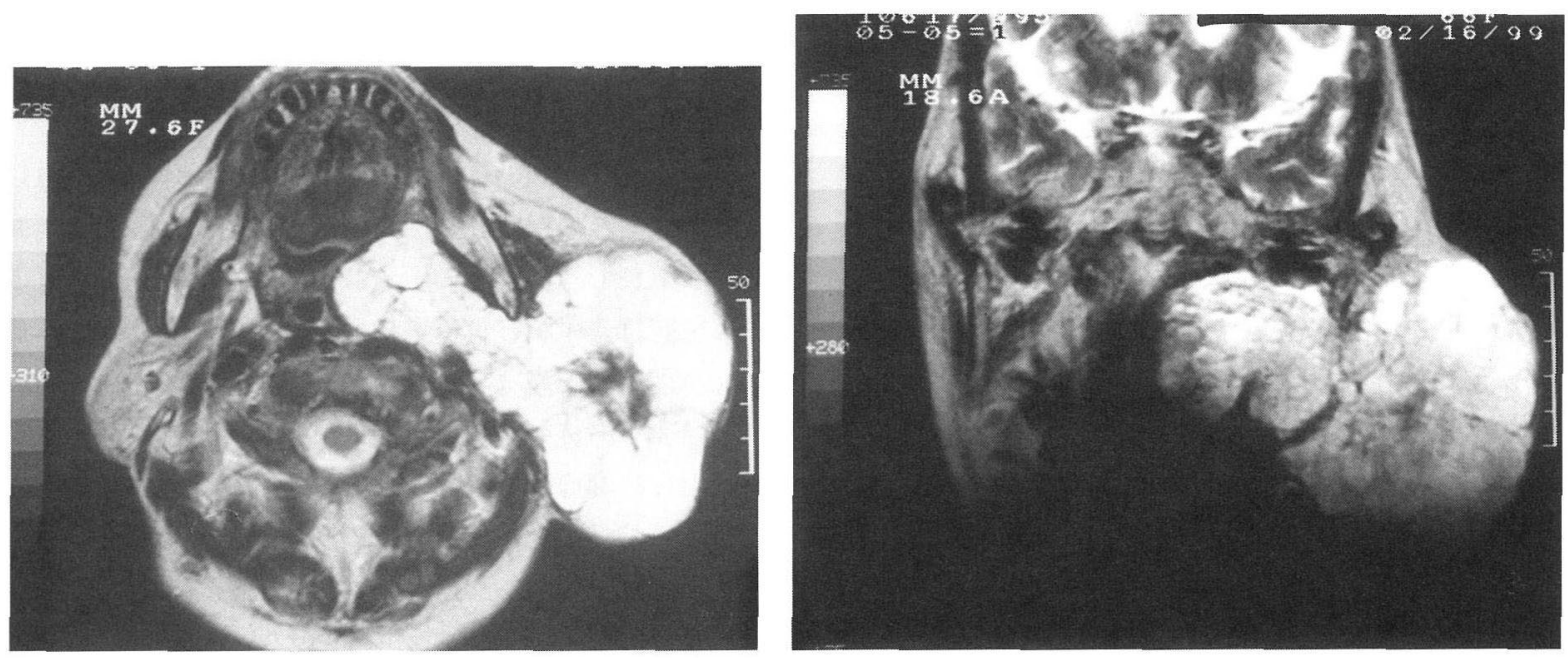

図 2 MRI T2 強調画像 (左: 水平断, 右 : 冠状断) 左 : 左耳下部から左副咽頭間隙にかけて巨大な腫瘍性病変を認め, ダンベル型を呈している. 右：腫瘍は頭蓋底へ進展している. 


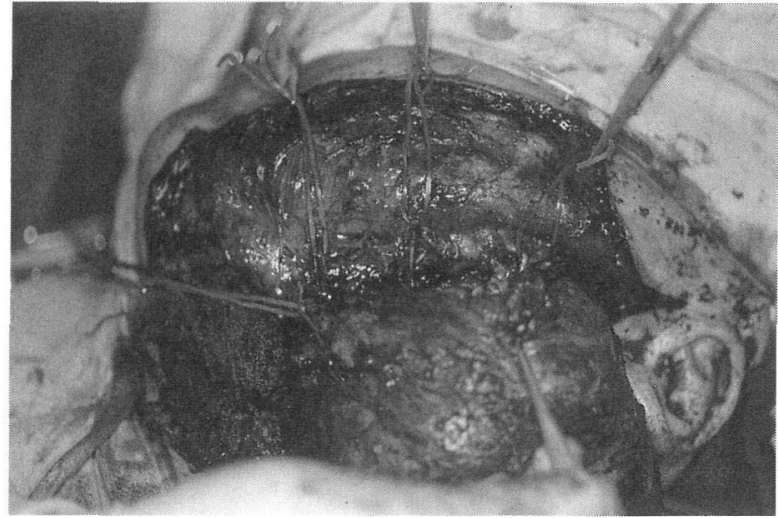

図 3 術中所見

顔面神経は本幹から末梢にかけて多数の娘結節のなかを 賷く形になっていた。

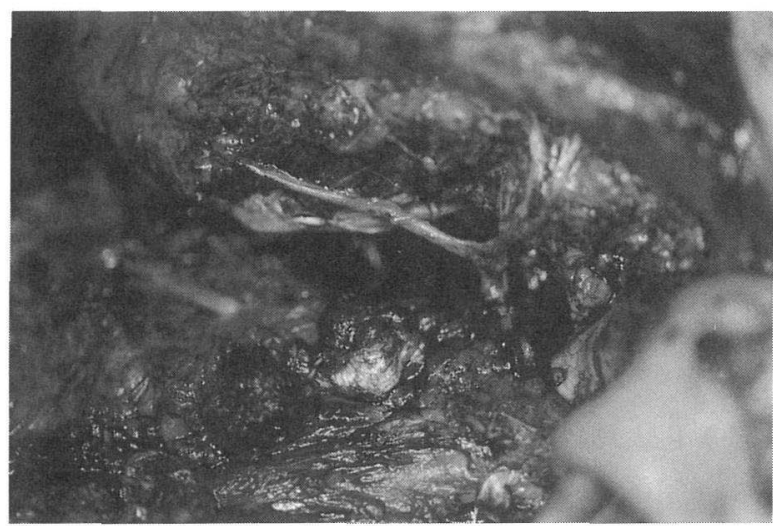

図4神経移植

左頸神経叢を用いて神経移植を行った。

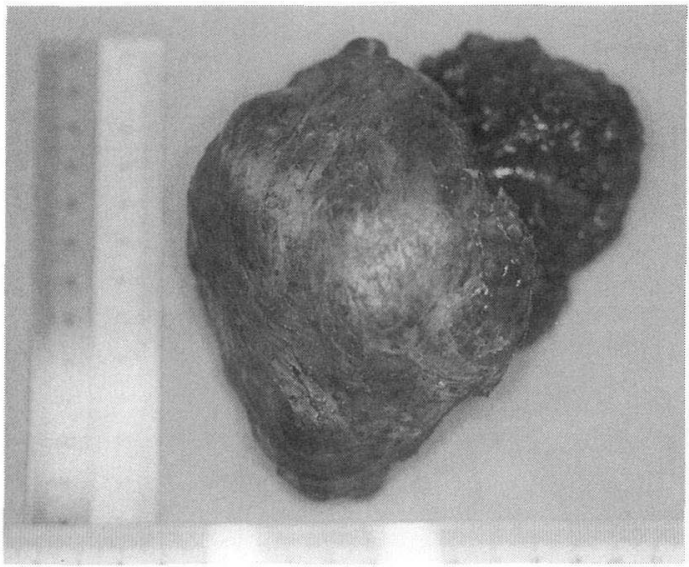

図 5 摘出標本

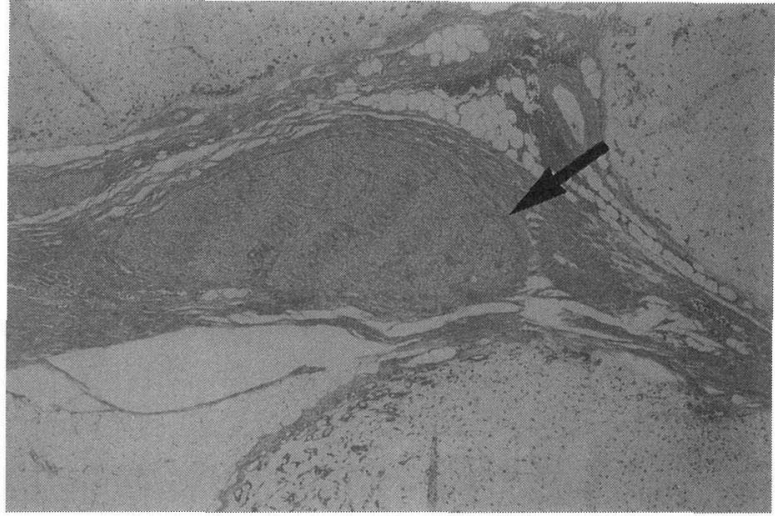

図 6 病理組織所見 $(\mathrm{HE}$ 染色, $\times 100)$

娘結節の間を顔面神経(矢印)が走行している.

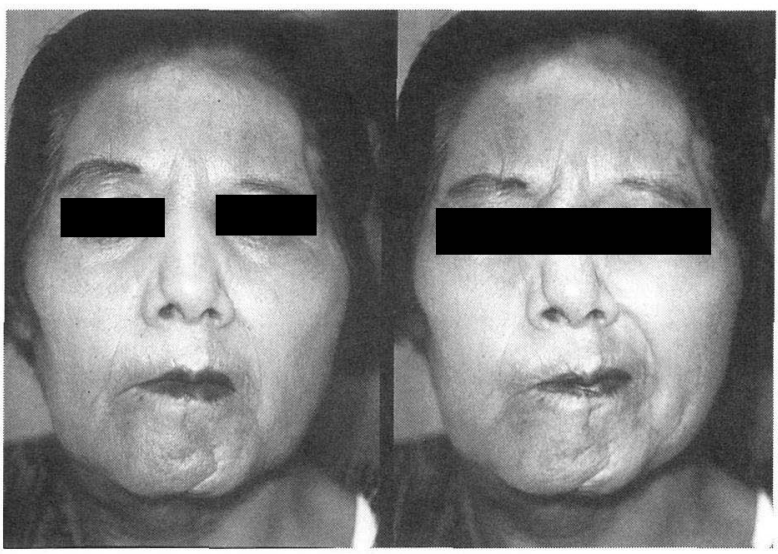

図 7 術後 1 年 6 力月の顔貌

閉眼，顔の緊張などは良好である。

病理所見：筋上皮之腺上皮が混在して扮り，基質には 広範な粘液産生が観察され多形腺腫と診断した。周团と の境界は明膫であるが，腫瘍成分が娘結節を形成しつつ

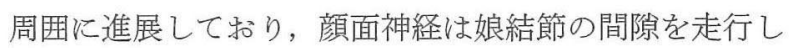
ていた（図 6)，悪性化の所見は認めなかった。

術後経過: 術後 2 年たった現在, 再発は認めず, 顔面 神経麻痺は 6 力月後より徐々に回復し 40 点法で18点まで 改善した. 20 年前に交通事故で左前額の完全麻痺があり， 術前から34点であったこと, 閉眼, 顔の緊張などは比較 的良好であることから (図 7 ), 患者の満足は得られてい る。開口障害や咬合不全は認めていない。 


\section{考察}

耳下腺腫瘍のなかで多形腺腫は最も頻度の高い腫瘍で

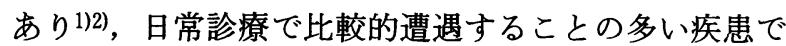
ある. 進行は緩徐で患者も腫瘤に気付いてから早期に医 療機関を受診することが多いことから，近年巨大な耳下 腺腫瘍に遭遇することはまれである3). 今回の症例も 30 年前に他院で診断を受けていたが，手術による顔面神経 麻疩を恐れ，手術を拒否し放置していた，本症例のごと く非常に巨大な腫瘍で, 長期に放置していたものは多形 腺腫内癌の発生を考慮する必要がある. Eneroth ら5) は 発生してから 15 年以上の症例では $9.6 \%$ に多形腺腫内癌 が発生していたと報告している。また Nagao ら6) は耳 下腺由来の多形腺腫の場合 $5 \mathrm{~cm}$ 以上のものでは悪性化 の可能性が急に高くなると報告している. 本症例の術前 の穿刺吸引細胞診では悪性所見は認めなかったが，この ような巨大腫瘍では腫瘍内がすべて悪性ではないと術前 に判断することは不可能であり,むし悪性化を認めた場 合は術中, 術後に対処せざるを得ない，幸い本症例は術 後の病理学的検討で悪性所見は認めなかった.

術式については腫瘍が非常に大きく, 副咽頭間隙に深 く進展していたことから, 術前より下箩正中離断と神経 移植の準備をして手術に臨んだ. 耳下腺悪性腫瘍や，良 性腫瘍でも再発例では顔面神経を合併切除する場合があ るが，良性の多形腺腫で顔面神経を切除せざるを得なく なる症例はまれである．本症例は多数の娘結節を形成し て腫瘍が顔面神経を取り込むように成長しており, 神経 を温存して腫瘍を摘出するためには腫瘍の一部を削り取 らなければ不可能と考えられた．村上7)はこのような症 例では，「腫瘍を削れば細胞播種は免れないから，後日 多発性再発を覚悟しなければならない，とすればせっか く神経を温存してもいずれは合併切除せざるを得ないこ とになり，長い眼でみれば手術に失敗したことになる。 そこで，顔面神経を付けたままの状態で腫瘍の完全摘出 を図り，同時に神経移植による再建を行らことになる.」 と述べている，本症例のごとくたと良性腫瘍であって も神経を保存できない場合があることを念頭に置く必要 がある.

顔面神経を切除した場合は，顔面神経同士の直接吻合 が理想的であるが切除範囲が長い場合は通常神経移植を


が多(889) が，本幹と末梢の 3 枝を吻合するために分枝 していて比較的長く神経を採取できる頸神経丵10)が有
用であった．麻㽻の改善は顔面神経どうしを直接吻合す る場合が最も改善率が良く，また若年者で切断されてか ら修復までの期間が短いほど回復が良い9．村上7)は主 幹で顔面神経を切断してから 3 本に分岐する移植神経を 介して再建した場合は，手技的に完璧を期しても60\%前 後の回復しかなし得ないと述べている．本症例の麻痺の 改善については閉眼可能で口角の動きも良好で顔面の緊 張も良いことょり，今のところ患者の満足は得られてい る. しかし麻疸の改善とともに，神経移植を行った場合 は病的共同運動は必発であり，それに対して今後患者か らの訴觉があれば対応していく必要がある.

下靧を離断するかどらかについては，耳下腺腫瘍の場 合, 腫瘍が深葉や副咽頭間隙に進展した症例であっても 経耳下腺法で下顎を離断せずに摘出可能な場合が多い. 今回の症例では顔面神経本幹を切断し顎二腹筋，茎突舌 筋，茎突下顎勒帯などを切断することにより，かなりの 部分が用手的に剥離可能であったが一塊で腫瘍を摘出す るためには頭蓋底付近での盲目的操作による神経や大血 管の損傷の危険があると考劣，また，分割切除では腫瘍 細胞の播種が危惧されたため，最終的に下顎正中離断を 行った.

\section{結 語}

1 ）巨大な耳下腺多形腺腫を経験した.

2 ）腫瘍摘出のために顔面神経の合併切除および，下 靧正中離断が必要であった。

3 ) 頸神経叢による神経移植を行い，良好な麻痺の改 善を認めた。

4 ）巨大な耳下腺腫瘍の場合，たと兄良性腫瘍であっ ても顔面神経を合併切除せざるを得ない場合があること を念頭に置く必要がある。

本論文の要旨は第26回日本耳鼻咽喉科学会中国四国連合学会 (平成12年12月，岡山)にて口演した.

\section{参考文献}

1) 村川哲也, 小坂道也, 森 聡人 : 耳下腺腫瘍の臨床統計. 香川労災病院雑誌 $5: 49 \sim 55,1999$.

2）井上俊哉, 山下敏夫, 辻川覚志, 他 : 当教室 10 年間に振け る耳下腺腫瘤の統計。耳鼻臨床 $82 ： 245 \sim 250,1989$.

3）大谷 祳, 小川 洋：巨大な耳下腺多形腺腫. 耳鼻臨床 $93: 184 \sim 185,2000$.

4 ）小松崎篤, 富田 寛, 柳原尚明, 他 : 末梢性顔面神経麻疩 
の治療効果判定についての申し合わせ事項試案. Facial N Res Jpn 15 : 227 230, 1995.

5 ) Eneroth CM and Zetterberg A : Malignancy in pleomorphic adenoma ; a clinical and microspectrophotometric study. Acta Otolaryngol $77: 426 \sim 432,1974$.

6 ) Nagao K, Matsuzaki O, Saiga H, et al. : Histopathologic studies on carcinoma in pleomorphic adenoma of the parotid gland. Cancer 48 : 113 121, 1981.

7 ) 村上 泰 : 顔面神経麻瘒の神経移植 一耳下腺腫瘍手術の 場合一. JOHNS $16: 439 \sim 443,2000$.

8 ) May M : Nerve repair. The Facial Nerve (ed by May M and Schaitkin B). pp 571 609, Thieme, New York, 2000.

9 ) 村上信五 : 神経移植のコッ 1 一顔面神経移植一. JOHNS $14: 743 \sim 747,1998$.

10）岡本美孝: 神経移植のコッ 2 一神経移植手技とその要点 一. JOHNS $14: 748 \sim 752,1998$.

/原稿受付 : 平成13年 2 月 21 日 原稿採択 : 平成13年 4 月 18 日 別刷請求先 : 小坂道也 干763-8502 丸亀市城東町3-3-1 